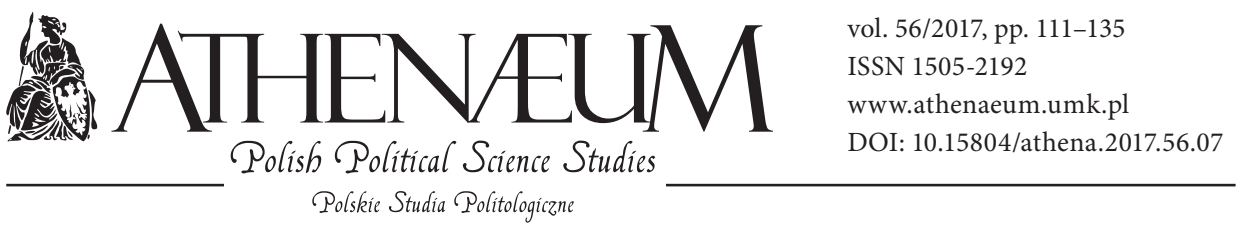

\title{
RUSSIAN GEOPOLITICAL ADVANCEMENTS IN THE BLACK SEA REGION: THE ANNEXATION OF CRIMEA
}

\author{
ROSYJSKIE POSTĘPY GEOPOLITYCZNE \\ W REGIONIE MORZA CZARNEGO: ANEKSJA KRYMU
}

Ostap Kushnir*

\begin{abstract}
The annexation of Crimea is not an ordinary event in contemporary international relations. Since WWII, there has been no precedent in Europe when one state under dubious premises has forcefully annexed a part of another state. This article scrutinizes the Crimean case in the context of the ongoing Ukrainian crisis and uncovers the rationale behind Russia's aggressive policies in the Black Sea Region. To accomplish this task, several steps have been undertaken. Primarily, the recent speeches of Russian officials and Kremlin-originated documents have been analyzed. Secondly, the tactics favored by the Kremlin to achieve its geopolitical goals have been explained and assessed (through applying frameworks of meta-geography and soft power security). Thirdly, the future prospects for Crimea with its gradual transformation in the counterNATO fortress have been outlined.
\end{abstract}

Aneksja Krymu nie wydaje się być zwykłym wydarzeniem we współczesnych stosunkach międzynarodowych. Od czasów II wojny światowej nie doszło jeszcze do precedensu w Europie, kiedy jedno państwo na podstawie wątpliwych przesłanek forsownie aneksowało fragment innego państwa. Ten artykuł ma za zadanie analizę aneksji Krymu w kontekście trwającego kryzysu ukraińskiego i określenie podstaw agresywnej polityki Rosji w regionie Morza Czarnego. W tym celu zostały podjęte następujące kroki. Przede wszystkim przeanalizowane zostały ostatnie wypowiedzi rosyjskich urzędników i oficjalne dokumenty Kremla. Po drugie, opisana i wyjaśniona została (poprzez zastosowanie metodologii meta-geografii i soft power security) ulubiona taktyka Kremla do osiągania swoich celów geopolitycznych. Po trzecie, przedstawione zostały perspektywy rozwoju Krymu uwzględniające jego stopniową transformację w antynatowską twierdzę.

\footnotetext{
* Lazarski University, Department of Government Studies.
} 
Keywords: Ukrainian crisis, Black Sea Region, Russian geopolitics, Russian foreign policy, Crimean annexation, critical geopolitics, metageography
Słowa kluczowe: kryzys ukraiński, region Morza Czarnego, rosyjska geopolityka, rosyjska polityka zagraniczna, aneksja Krymu, geopolityka krytyczna, meta-geografia

\section{INTRODUCTION}

The chain of events which started in Ukraine on the 21 of November 2013 and continues up to now, came as a shock to many. On that day, the authorities of Ukraine officially suspended the state's European aspirations, this action triggered massive anti-governmental rallies. These rallies became extremely violent over time, encouraging external intervention in the originally internal conflict. Consequently, Ukraine lost the Crimean peninsula to Russia and has since plunged into war with Russian-backed separatists in its eastern part (Tsygankov, 2015). Western states, in their turn, faced with the first forceful breach of sovereignty in Europe in the new millennium, imposed sanctions to cool Russia's aggressive behavior down, and as such a revival Cold War discourse can be observed.

It is in everyone's interest to have Ukraine as a peaceful and cooperative partner. From the geopolitical perspective, the state is situated on one of the world's major crossroads, in particular on an intersection of Europe-Asia and Nordic-Mediterranean transport corridors (Delanoe, 2014; Götz, 2015; Kushnir, Domaradzki, 2013). Its position on the northern Black Sea shores also provides Ukraine with a strategic depth in promoting regional trade and security. However, external actors tend to perceive their cooperation with Ukraine differently. On the one hand, the West considers Ukraine as a self-sufficient player which requires assistance in strengthening its democracy, free market, and goodgovernance. This modus operandi seems to be coherent and attractive for present day Ukrainians, as proved by their participation in the anti-governmental rallies (Wawrzonek, 2014). On the other hand, Russia is keen to keep Ukraine within its political orbit, thus establishing some kind of a supervised "buffer zone" between mainland Russia and the rest of Europe (Götz, 2015).

Actually, Russia seems to be one of the most ambitious and ambiguous actors in the region. Its behavior is not always rational, but fueled by the geopolitical necessity to expand and attempts to restore "historical justice" - at least this is how the Kremlin perceives it (Horbulin, 2015). 
As one may recall, the Black Sea became a Soviet controlled "pool" after World War II. However, the Kremlin's domination in the region was severely undermined by the USSR demolition after the Cold War. Sovereign Russia yielded influence over its former satellites - Bulgaria and Romania - with their Black Sea ports and industries. The most of the northern coastline was "inherited" by the re-emerged Ukraine. These and other factors triggered geopolitical discomfort for Russia; its presence in the Black Sea littoral was limited to around $450 \mathrm{~km}$ of the coastline on the Caucasus (Delanoe, 2014). Here lies the root of the "historical injustice" - Russia, as the direct descendant of the USSR, was stripped of its significant maritime possessions it perceived as indisputably Russian. Throughout the recent decades the Kremlin drew plans to bring these lands back and - simultaneously - re-establish control over the "pool". The annexation of Crimea, as well as earlier Russian engagement in Transnistria, Abkhazia, and Adjara (unsuccessful), were nothing but firm steps to fulfill these plans.

To achieve its goals in the post-communist space, the Kremlin utilizes various tactics which can be generally defined as the export and subsequent enrooting of the Russian model of governance (Socor, 2005; Jackson, 2006). This model presumes the presence of strong authoritarian leaders whose powers are nourished by organized crime and the state's secret services. On acquiring key positions, these leaders introduce a sophisticated bureaucracy, which in its turn cultivates "shadow" economics and establishes indirect governmental supervision over big and/or strategic enterprises. The legitimacy of such a political shift is not questioned as an aggressive media brainwashing and the blatant prosecution of political opponents is pursued. The way Crimea was annexed can provide a bright example of these tactics in action. What are worse, Kremlin agents were able to fulfill their tasks because of the passiveness of the Ukrainian authorities and the lenience of a "united" Europe. In a word, the key decisionmakers in Kyiv and in the West disregarded the first signs of the Kremlin's geopolitical offensive.

This article addresses the issue of the annexation of Crimea by Russia from various perspectives. Primarily, it describes and explains the way Russia supported and cherished Crimean separatism between 1990 and 2014. Secondly, it uncovers and critically assesses the rationale behind Russian revisionist and expansionist politics in the region. Thirdly, it scrutinizes the tactics utilized by the Kremlin to achieve its geopolitical goals (on the example of Crimea). Finally, it reveals the geopolitical importance of Crimea to Russia, as well as draws prospects of the development of the peninsula for the nearest future. 
As the methodology is concerned, it will reside in combining classical and critical geopolitics. The first - state-centered Hobbesian approach - will allow to explain the rationale behind the Russian aggressive behaviour in its neighborhood. It seems feasible - on the first glance - that such type of behavior solidifies the power of the Kremlin on domestic level through evoking "rally around the flag" effect, as well as reassures the state's ability to project its power and national interests globally. In a word, classical geopolitics is a suitable tool to assess costs and benefits the Russian state experiences while conducting aggressive foreign policy. In its turn, critical geopolitics will allow to unveil the mechanisms which Russia utilizes to achieve its objectives in the post-Cold War world. The paradoxical assumption here is that Russia pursues national interests through a utilization of mechanisms which emerged in liberal democratic societies to limit the state's power (i.e., empowerment of the individuals and non-state actors, political pluralism, freedom of speech and communication, social networking, and others). One should particularly consider in this regards Colin Flint's metageographic frameworks (Flint, 2006).

\section{LOGICS BEHIND RUSSIAN AGGRESSION IN THE BLACK SEA REGION}

The beginning of 2007 was a milestone for contemporary Russian geopolitical expansion. At this moment several specific factors came into being: Russia regained its economic sufficiency and foresaw uninterrupted growth; the U.S. witnessed signs of domestic fatigue with the War on Terror and global engagement; the EU was to enter the first waves of economic crisis; the series of noticeable revolutions took place in the European neighborhood, and others. In a word, that was the time when the appropriate environment emerged which allowed Russia to re-draw its foreign policy and start the implementation of its old-new objectives.

On 12 February 2007, during the $43^{\text {rd }}$ Munich Conference on Security Policy, President Vladimir Putin delivered one of the key speeches of recent times. He outlined the forthcoming changes in the Russia's geopolitical objectives (Putin, 2007). In some respect this speech may be regarded as a declaration of Cold War 2.0; at least, it contained clear allusions to sinister Soviet rhetoric.

Putin seemed to speak honestly on his new modus operandi. He stated with bitterness that the world after 1991 became unipolar with the U.S. taking the unchallenged lead. That was a wrong turn, according to the President. The 
U.S. accumulated too much power thus making impossible the natural development of other sovereign entities; every state on the globe was doomed to exist in the shadow of Washington's interests. What was worse, these interests were not always complying with international law (Forsberg, Herd, 2015).

Putin also addressed the role of international organizations which he considered to be biased and one-sided. For instance, he declared that the OSCE acted as the U.S. and the EU subsidiary, not as a neutral force for common good. As he put it: "People are trying to transform the OSCE into a vulgar instrument designed to promote the foreign policy interests of one or a group of countries" (Putin, 2007). Referring to NATO, Putin stressed its "two-faced" nature. To prove this, he mentioned the Alliance's expansion into Eastern and Central Europe, contradicting the promises given by the NATO General Secretary Manfred Wörner to the Soviet Union on 17 May 1990. In a word, on the OSCE and NATO examples Putin demonstrated his proneness to perceive international organizations as nodes in Western networks. This should be kept in mind in order to explain contemporary Russian political behavior.

Apart from this, Putin sent a clear message to the world that the Kremlin would defend its interests as never before. That would be a proper response on the external provocative actions. According to the President, his state had always been "cheated" by its Western "partners" through empty promises, unilateral actions and unfulfilled obligations. This should not and would not be the pattern in the future: "We very often [...] hear appeals by our partners [...] to the effect that Russia should play an increasingly active role in world affairs. In connection with this I would allow myself to make one small remark [...] Russia is a country with a history that spans more than a thousand years and has practically always used the privilege to carry out an independent foreign policy. We are not going to change this tradition today. At the same time [...] we would like to interact with responsible and independent partners with whom we could work together in constructing a fair and democratic world order that would ensure security and prosperity not only for a select few, but for all" (Putin, 2007).

As one may see, Putin's speech in Munich signaled the climax of Russia's dissatisfaction with the current state of affairs. The President argued that the global architecture was unjust, the U.S. undermined principles of international coexistence, and Russia found itself in a position of geopolitical inferiority ${ }^{1}$.

1 The same objectives were reiterated in the Foreign Ministry report A Review of the Russian Federation's Foreign Policy published on 27 March 2007. The report presented Russia as a power ready 
To fix these flaws, Putin announced his state's likely return to the Soviet-style non-compromised policies (Hughes, Sasse, 2016).

Seven years later, on 18 March 2014, Putin delivered another noticeable speech (Putin, 2014). That was his address to the Federal Assembly of the Russian Federation in the Kremlin. The speech - commonly referred today as the Crimean speech - was delivered on the eve of the military conflict bursting out in the Donbass region, Eastern Ukraine. That speech stressed, factually, the same points and positions as they had been outlined in 2007.

Primarily, Putin reiterated that there was no longer stability after the dissolution of the bipolar world. The U.S. along with its allies were inclined to undermine international order and instead preferred to follow the "rule of gun", not the rule of law. Russia as the USSR successor felt itself plundered and robbed in the environment of the U.S. hegemony ${ }^{2}$.

Secondly, international institutions and organizations discredited themselves in ensuring global security and order. Putin considered them to be nothing but biased agents acting under the supervision of Western states.

Thirdly, Russian interests were systematically ignored, especially in the postcommunist space. Putin was of the opinion that Western states were constantly lying to him about their intentions and future actions (i.e., NATO expansion, EU neighborhood program, and others; Forsberg, Herd, 2015; Götz, 2015; Tsygankov, 2015). Moreover, they were always secretly conducting the policies of "containment", thus attempting, as Putin said, "to sweep us into a corner because we have an independent position" (Putin, 2014).

Finally, Putin underlined that no one should underestimate Russia's deliberation to take decisive and "just" actions: "Russia is an independent, active participant in international affairs; like other countries, it has its own national interests that need to be taken into account and respected" (Putin, 2014).

There were, however, some new interesting points in the address to Parliament. For instance, Putin presented recent revolutions - so called "colored" revolutions - in the post-communist space as Western-inspired and Western-orchestrated (Darczewska, 2014). These revolutions brought nothing but harm to the citizens

to influence international relations by challenging the actions of others if they were "unilateral" and disrespectful of international law (for more details see: Tsygankov, 2015).

2 As Forsberg and Herd present it, Putin's Russia struggles to replace the U.S.'s "power vertical" with a "democratic multi-polarity" and "a new version of interdependence". Putin also considers his state to be on "the right side of history", aiming to become an independent pole in this post-Western global order (for more details see: Forsberg, Herd, 2015). 
of the targeted states; new emerging orders completely disregarded the "way of life, traditions, and cultures of the indigenous population" (Tsygankov, 2015). Thus, Putin presented these revolutions as artificial, bringing illegitimate elites to power. In the case of Ukraine, he stated that the forces behind the 2014 Maidan "resorted to terror, murder and riots. Nationalists, neo-Nazis, Russophobes and anti-Semites executed this coup" (Putin, 2014).

In respect to the annexation of Crimea, Putin stressed that "Crimea is our common historical legacy and a very important factor in regional stability. And this strategic territory should be a part of a strong and stable sovereignty, which today can only be Russian" (Putin, 2014). Except for the symbolic and strategic importance of Crimea to Russia, Putin perceived the annexation as a "right and just action". He claimed that Crimea had been given to Ukraine in 1991 as a "sack of potatoes" with Russia being too weak to claim its rights on the peninsula. In between 1990-2014, Russia had to restrain its Crimean ambitions because of its respect to Ukrainian sovereignty. However, as Putin presented it, the 2014 illegitimate coup détat in Ukraine provided Russia with a legitimate right to act (Putin, 2014).

Both of the above-mentioned speeches unveil the implementation of Russia's behavioral patterns provisioned by Klaus Dodds in 2007 (Dodds, 2007). These patterns derived from the excessive assertiveness the Bush administration implemented in its War on Terror, thus undermining the global geopolitical architecture. Therefore, Putin's interventions in Georgia (2008) and Ukraine (2014) are nothing else but attempts to mirror the ambiguous U.S. actions. However, Putin not only mirrors these actions, but provides them with specific meaning to meet Russia's objectives. Both speeches mentioned above - as well as a majority of Putin's other public speeches - clearly illustrate this. Utilizing aggressive policies, as Putin accuses the U.S. to utilize, Russia re-draws the world order, gains global weight, and withstands its national interests (Forsberg, Herd, $2016)^{3}$.

3 Gerber and Zavisca define the contemporary Russian political and media narrative in the following way: "1) the United States is a powerful but malign force that seeks to dominate and subjugate the world; 2) it pursues this aim by fomenting instability, chaos, and, ultimately, «color revolution» in countries it perceives as rivals; 3 ) its means of doing so include funding groups that oppose the legitimate leaders of these countries and otherwise promoting discontent under the guise of support for abstract institutions it calls «democracy» or «human rights»; and 4) Russia, with its resources and its alternative institutions and culture, is the only force in the world capable of resisting U.S. domination and control" (for more details see: Gerber, Zavisca, 2016). 
Putin seems to be sure that Western states perform "orchestrated revolutions" or "legalized interventions" in order to lead their favorites to power in key states or regions. At least this may be indirectly deduced from the 2002 National Security Strategy which outlines the U.S. objectives in the War on Terror. In particular, the Strategy articulates the U.S. intention to "defend the peace by fighting terrorists and tyrants" (The National Security Strategy..., 2002). This statement may be widely interpreted; thus, the 2002 Security Strategy - along with the next years' Strategies and similar documents - provide a fertile soil for Kremlin analysts to claim that the U.S. secret services are actively engaged in fighting "legitimate authorities" in third states overseas (i.e., Syria, Libya, Iraq, Egypt and others). This is where the U.S. national interest resides. Therefore, Russia as an actor with global ambitions should follow - apparently - the same pattern of the "strong".

This pattern, by the way, was outlined for the first time in the 2000 Russian Military Doctrine (Military Doctrine of Russian Federation, 2000) and re-stated in the Military Doctrine of 2010 (Military Doctrine of Russian Federation, 2010). Both documents appeared during Putin's time in power. Both clearly specify the key military dangers for the Russian Federation which may require military responses. In the Doctrine of 2010 one should particularly consider provisions $8 b, 8 d, 8 u$, and 20 .

The provision $8^{b}$ states that any attempt to destabilize the situation in various countries and regions, thus undermining their strategic stability, poses a danger to Russia. The provision $8^{d}$ defines as dangerous any territorial claim against Russia and its allies, as well as interference in their internal affairs. In its turn, the provision $8 u$ justifies Russia's action in case there is the emergence of any armed conflict on the territories adjacent to Russia or it allies. All three provide carta scribi rationale for Russian engagement into global and regional affairs. Apparently, the Kremlin reserves itself the right to define the magnitude of any global or local danger.

As far as military action is concerned, the provision 20 states that Russia finds it appropriate to (i) use armed forces in case of external aggression against it or its allies; (ii) in case the UN or any other collective security body initiates peacekeeping or peace restoring mission; or (iii) in case Russian citizens require protection overseas (Laruelle, 2015). It is clearly stressed in the Doctrine that if armed forces are called into action, Russia will operate within the frameworks of international law and its international obligations. The final decision on deploying troops belongs to the President of Russia. 
Much in line with what the Russian Military Doctrines claim can be discovered in the recent 2014 Kremlin-originated report On Russia's National Identity Transformation and New Foreign Policy Doctrine (Zevelev, 2014). According to Zbigniew Brzezinski, the report provides justifications for the Russian harsh policies abroad: "The key concepts of this report are four: first, that of «a divided people»; secondly, the theme of "protecting compatriots abroad»; third and more broadly, «the Russian World» or «Ruski Mir» in Russian; fourth, the importance of acknowledging and sustaining, embracing and promoting «the Great Russian civilization». I mention this because I think it would be an error to think that Crimea and Ukraine are just the products of a sudden outrage" (Brzezinski, 2014).

As one may deduce, Brzezinski argues that the Russian authorities are deliberate to construct - or restore - what they call the Great Russian civilization". They are prone to accomplish that task through the strengthening of Russia's presence in the states with significant Russian minorities or simply Russian speaking people. Hence the task is treated as right and historically decisive and almost sacred, any occurring conflicts of interest are likely to be disregarded or - whether possible - resolved by the implementation of international law ${ }^{5}$. Russian deliberation to achieve the favorable results is so significant that Putin demonstrates his readiness to challenge the global balance of power, openly assaulting the U.S. and Western states, and to provide military assistance to the third parties, and even put the welfare of Russian citizens at risk (Kushnir, 2016).

4 The same as Brzezinski, Szostek states that the contemporary Russian authorities are accomplishing "Civilizational Mission" which, to the word, is widely supported by the common people. According to Szostek, this mission emphasizes "the distinctiveness of Russia's culture and values and its responsibility to protect and unify those with whom it has historical ties. Russian-speakers in neighboring states are considered «compatriots» (sootechestvenniki), whose «educational, linguistic, social, labor, humanitarian, and other rights» Russia must protect" (for more details see: Szostek, 2014).

5 Emphasizing sacredness of the Russian "Civilizational Mission" one should consider the spiritual principles of the so-called "Russian World". Having analyzed the public speeches of the Russian Orthodox Church leaders, Wawrzonek concluded that "the Russkiy Mir is a separate and autonomous civilizational space, formed [...] by elements such as the spirit of tolerance and respect for the rights of dissenters, Russian language and culture, and «common views on social development». According to Patriarch Cyril, the mentioned former values have been established by the «common boundaries and one geographical area in which our people lived» (here one should consider Kievan Rus, Russian Empire, and Soviet Union)" (for more details see: Wawrzonek, 2014). 
To draw some intermediary conclusions, in 2007 Russia entered a new era in its foreign policy which envisages unilateral attempts to reshape the post-Cold War order. These attempts are mainly inspired by a specific interpretation of the U.S. global actions during the War on Terror and the evolution of the EU's neighborhood policy. Russian authorities - and President Putin in particular - perceive the recent Western activities as a special kind of military or "soft power" operations which allow for the establishing of legal supervision over key states or territories. Moreover, Russian authorities attempt to follow the "Western example": Crimean annexation is the brightest example and the biggest Russian success in this regard. To commemorate it, Putin even proclaimed 27 February to be the Day of Secret Services in Russia - that was the day the Russian flag weaved over the Crimean parliament in 2014 for the first time.

\section{THE CASE OF CRIMEA: HOW RUSSIA MADE IT}

It was the U.S. Secretary of State John Kerry who argued that in order to achieve its goals in the $21^{\text {st }}$ century Russia utilizes the $19^{\text {th }}$ century tactics "by invading another country on completely trumped up pretext" (Dunham, 2014). However, upon deeper scrutiny, this statement may appear to be arguable. The fact is Russia does not apply straightforward tactics of military intervention; its behavior in recent conflicts is more complex and smart. To explain this with the Crimean example, one should consider the meta-geographical framework advocated by Colin Flint within the critical geopolitics approach. Flint states that: "Geopolitics is not just the calculation of countries trying to expand or protect their territory and define a political sphere of influence; it is also about countries, businesses, and political groups making connections across the globe [...] Political power is not just a matter of controlling territory, it is also a matter of controlling movement, or being able to construct networks to one's own advantage across political boundaries" (Flint, 2006).

In a word, it may seem that the old-fashioned state-centered geopolitics has given its positions up in the liberal democratic environment; the trans-national networks and cross-boundary cooperation are what matters now. Those actors - especially non-state actors - who can establish and control such networks are taking the lead in global decision-making and projecting their influence on new territories. That is the truth Kremlin analysts have perfectly learned, converted 
in accordance to their needs, and started to utilize when pursuing their state's interests ${ }^{6}$.

The pro-Russian networks in Crimea existed in a dormant state since the $1990^{\text {s }}$ and were promptly awakened with Putin's coming to power in 2000s. These networks incorporate several key nodes, among them are the Russian intelligence, Russian military bases with their infrastructure, the Russian Orthodox Church, pro-Russian NGOs, Russian media, and others. In 2006, the Secret Service of Ukraine (SSU) in one of its reports pointed out these nodes and warned about dangers they can inflict on the state. According to Taras Kuzio, the report was not perceived with all due cautiousness though (Kuzio, 2006; ICC News Digest, 2006).

To assess pro-Russian nodes and their efficiency with more precision, one should consider the 2011 research by Lada L. Roslycky. The latter presented and assessed Russian activities in Crimea as the "soft power" security threat for Ukraine. Through utilizing its informal, but all-penetrating presence on the Crimean peninsula, the Russian side managed to switch the attention of the indigenous people "from the interests of the state to which they belong and toward the interests of the intervening actor" (Roslycky, 2011). In a word, Russian side attempted to pursue its national interest not through applying brutal power, but through working with networks and the persistent formation of a favorable socio-political environment - with brutal power as the ultimate argument for nonconformists. This tactics bared its fruits on the "volatile" soil of Crimea and can be scrutinized through the prisms of meta-geography and critical geopolitics.

Speaking of the presence of Russian intelligence services in Crimea, their key mission resided in securing the Black Sea Fleet deployed at the Ukrainian territory and monitoring the dynamics of regional affairs. Apart from this, according to Kuzio, Russian intelligence attempted to shape the social moods and political

6 One should consider the so-called Gerasimov Doctrine in this regard. In 2013, Russian Chief of General Staff Valerii Gerasimov emphasized that the role of non-military means of achieving political and strategic goals has exceeded the military operations in their effectiveness; the non-military operations should occur at a rate of 4:1 over military operations. Gerasimov raised the importance of nurturing social dissatisfaction within the target state, undermining the authority of local governments, weakening the adversary's military potential, and creating a vacuum of power. This can be achieved, in particular, through manipulations with information and special operation in cyber-space. The armed forces - under the peacekeeping disguise - should arrive on the final stage of the conflict to secure the success (for more details see: Gerasimov, 2013). 
life in Crimea through collecting secret information, conducting pro-Russian propaganda, and providing indirect support to separatist powers (Kuzio, 2006). Russian intelligence strove to incorporate their agents or sympathizers into the republican government, local administrations, law enforcement services, and civil society. As Roslycky argues, “Ukraine’s intelligence services identified Russian intelligence forces as targeting the most pivotal elements of Ukraine's power from within its own territory" (Roslycky, 2011).

Apart from Russian intelligence services, the role of the Black Sea Fleet should not be underestimated. At the beginning of 2014, the fleet was served by c. 12000 service men - including c. 3000 marines - stationed mainly in Crimea (Delanoe, 2013; Delanoe, 2014). To maintain that amount of people necessary infrastructure was erected - starting from barracks and shipyards, ending with schools and university. This kind of social-through-military policy could not but attract Crimeans and shape their world views. Apart from this, Russian marines and officers often befriended local people and had families with them, this tightened "international ties" even more. Therefore, the "soft" and "hard" power the Black Sea Fleet possessed - including the network of people united around the fleet - was another significant factor contributing to the success of the annexation of Crimea.

As far as the NGOs are concerned, a majority of them functioned as double agents. Officially, their aim resided in the promotion of inter-cultural dialogue and trans-boundary cooperation; this was justified and appropriate for the region with significant Russian-speaking population. Unofficially, they were nurturing anti-Ukrainian moods among civil society and promoted ideas that Crimea should be "returned" to Russia. Apart from this, numerous organizations were also suspected by the SSU in conducting direct separatist activities or money laundering (Kuzio, 2006). In particular, one should speak here about the Russian Community of Crimea and the youth pro-Russian movements: Proryv, the Eurasian Youth Union (till 2011), and Nashi. These organizations also functioned in other separatist areas in the Black Sea Region, namely in Transnistria, Abkhazia, and South Ossetia. For extra efficiency, they were closely cooperating with Russian intelligence, Russian military, and local organized crime groups (Roslycky, 2011).

Another node in the network constituted Russia's mass-media. Factually, one should distinguish here between Russian-owned and Crimean pro-Russian mass-media. The latter were well-financed from local sources; this allowed them to produce high-quality materials or buy Russian production, thus attracting 
wider numbers of consumers as if to compare with the mainland Ukrainian or Crimean independent media. As Russian-owned media are concerned, they were traditionally enjoying high viewers' and readers' rates. They were also granted a right to broadcast or distribute materials with no restrictions in Crimea (Szostek, 2014). In their activities both kinds of mass media aimed to discredit Ukraine as a sovereign state and undermine Kyiv's European and Trans-Atlantic aspirations. They also cherished pro-Russian moods in society and nurtured nostalgic feelings for the Soviet times (Gerber, Zavisca, 2016). The new media including numerous social networks and blogs - pursued the same goals, but targeted younger generation.

According to Jolanta Daczewska, Russian-owned and pro-Russian mass media in Crimea were implementing principles of political propaganda in their activities. One should consider in this regard (i) the principle of massive and longlasting impact (media were constantly reiterating key anti-Ukrainian slogans and stereotypes; for instance, Ukrainian-speaking people were presented as fascists), (ii) the principle of desired information (on the one hand, media convinced Russians and Russian-speaking recipients that Ukrainian authorities would ban their language; on the other hand, media promised recipients sufficient assistance and cultural "salvation" from Russia), (iii) the principle of emotional agitation (media messages incited emotions and encouraged recipients to act without critical assessment of the acquired information), (iv) the clarity principle (media simplified their messages and divided the world into black-and-white), (v) the principle of supposed obviousness (media linked their messages to political myths: the Russian sentiment equals patriotism, Ukrainians equals fascists, Maidan equals chaos, etc.) (Darczewska, 2014). In a word, Russian media activity in Crimea provides an appropriate illustration to Valery Gerasimov's statements about the role of non-military means in achieving Russia's national interests.

The last but not the least among the key nodes of the Russian network is the Russian Orthodox Church. Roslicky and Wawrzonek argue that the Church always maintained strong connections with the Russian state (Roslycky, 2011; Wawrzonek, 2014). Indeed, in the era of developed absolutism - from 1654 to 1918 - it was the Monarch who headed the Church. In the communist times the activities of the clergy were supervised by the Secret Services. In modern times, clergy claims that Church must monitor political life in states that are Orthodox by nature and try to adjust it to the spirit of Orthodox civilization (Wawrzonek, 2014). Thus, the political role of the Russian Orthodox Church - regardless of the epoch - has always exceeded its religious and social mission. Concerning 
the Crimean case, the Orthodox Church regularly organized marches against the arrival of NATO vessels in Sevastopol or against the sole idea of Ukrainian cooperation with the West. The temples were often used to store pro-Russian or separatist literature. It also happened that the clergy encouraged people to share the Russian perspective in any political dispute; Russia was portrayed as the only force for good in the world of sin. Not to speak that Patriarch Cyril perceived Crimea as one of the pivots of "Holy Russia" and the "Russian World" (Suslov, 2014).

Obviously, there were other nodes in the Russian network on the peninsula Black Sea Branch of Moscow State University, Night Wolves motorcycle club, local self-defense forces, visiting Russian officials, and others. However, their long-term contribution to the annexation of peninsula was not as significant.

As the Maidan was coming to its end in Kyiv - in particular when President Viktor Yanukovych fled the country in February 2014 - Kremlin decision-makers activated all nodes in Crimea. Blockade and seizing the Crimean parliament, orchestrating the dubious appointment of Sergey Aksyonov as the Prime Minister, and finally the running of the pro-independence referendum - that would be impossible to complete within days without any preparation (Hughes, Sasse, 2016). Especially, in consideration to the Ukrainian Black Sea Fleet which was stationed in Sevastopol and the Crimean Tatars who were actively protesting against any anti-Ukrainian rallies.

On Aksyonov's coming to power, a traditional Russian model of governance was enrooted on the peninsula. The Prime Minister appeared to be an authoritarian leader backed by Russian intelligence, military, organized crime, NGO, and mass media. With their help, he almost immediately subdued or blocked those regional actors which could hypothetically sustain Ukrainian sovereignty. As the final accord, on the 16 March 2014, Aksyonov initiated a referendum on Crimean status searching for legal premises to secede the peninsula from Ukraine to Russia. With $95 \%$ of votes in favor of leaving Ukraine, the Kremlin - unlike the rest of the civilized world - recognized the referendum results and accepted Crimea as one of Russia's federal subjects (Hughes, Sasse, 2016).

As for now, Crimea de jure is Ukrainian, but de facto Russian. Aksyonov and his supporters installed the Russian state system on the peninsula with as little delay as possible. There were also border crossing points erected on the roads connecting Crimea to Ukraine. However, only several non-European countries in the world recognized the change of Crimea's status. That came as a surprise for the Kremlin. The non-negotiable position of the West and its pressure on Russia 
to follow the principles of international law - with the consequent imposition of sanctions - became a heavy and unexpected burden for the Kremlin. The fact that the majority of Crimean denizens represented Russian culture and ethnicities did not sound convincing. However, this is a topic for another research.

To draw intermediary conclusions, the annexation of Crimea was nothing, but a series of long-prepared secret operations under the supervision of Russian intelligence. It was perfectly calculated from the perspective of applying "hard" and "soft" power. To justify the change in Crimea's territorial belonging, the Kremlin referred to the provisions of Russian military doctrine and the UN Charter, reiterated its intention to protect compatriots abroad, and stressed the necessity of restoring the post-Cold War justice. Factually, as Russian officials - including the President - presented it, Russia had no other option but to intervene into Crimean affairs, taking into account the blatant events in Kyiv, emerging challenges to Russian sovereignty, and the threats for the Russian speaking people in Ukraine. Here one may recall the statement by Dodds who claimed that third states are prone to follow the U.S. example of conducting aggressive trans-boundary foreign policies. However, the rationale behind the U.S. War on Terror and Russian annexation of Crimea was different; and thus Russia's action triggered more than just criticism from key members of international society.

\section{THE FUTURE OF CRIMEA: WHY RUSSIA MADE IT}

Western political scientists tend to assess the annexation of Crimea from at least four major perspectives: (i) annexation as a revival of Russia's imperialism and power aspirations; (ii) annexation as Putin's attempt to consolidate power and address domestic issues; (iii) annexation as a hyper-reaction on democratic aspirations in the Russian "Civilizational Space"; and (iv) annexation as Putin's personal dissatisfaction with the Western policies in Ukraine and Ukrainian civilizational choice (Tsygankov, 2015). This research aims to prove that the rationale behind Russia's Crimean annexation resides in achieving geostrategic objectives which are largely predefined by the imperial traditions, memories, and fears that the Kremlin may irretrievably lose control over lands which were once Russian. It was in 1853 that Tsar Nikolay I welcomed the inclusion of island Sakhalin and Amur region into Russian Empire by stating: "Once the Russian flag is raised over it, let it never be lowered!". This statement, which was given 
a fresh breath in pro-Russian social networks after the annexation of Crimea, can partially explain the contemporary Russian expansionist politics.

The most obvious deduction concerning Russia's annexation of Crimea is that it was easy to accomplish in right time and circumstances. Throughout 25 years of state's independence no one in Kyiv seriously considered the systematic promotion of Ukraine's interest on the peninsula - especially the aspects of "soft power" and pro-Ukrainian networks. This could not but contribute to the fast and swift annexation of Crimea.

However, from another perspective, Ukraine's modest engagement into the affairs of Crimea can be explained as a problem of a young state with a complex territorial and ethnic composition. Decision-makers in Kyiv had neither experience how to govern over Crimea, nor full understanding of how important it was to establish good governance there. In its turn, Ukrainian civil society was not strong enough to efficiently raise the importance of Crimean issues. Not to mention Ukraine's oligarchs and post-Soviet elites were prone to keep the "informal practices" and non-transparent governance on the peninsula, this allowed them to generate significant "grey" incomes. Finally, no one in Ukraine perceived Russia as a serious threat; for a majority of the political elites, oligarchs, and civil society Russia has always been a "brotherly nation" with close historical ties.

However, the geostrategic and symbolic importance of Crimea to Russia was worth breaking amiable relations with Ukraine. It seems the Kremlin decisionmakers were simply waiting for the right moment.

It was in the $1940^{\text {s }}$ that Yuriy Lypa, one of the prominent Ukrainian geopoliticians, who argued that the state which ruled the Crimean peninsula commanded the whole Black Sea Region; Crimea was nothing but the command post of the Black Sea (Lypa, 1942). Little has changed since that time; geography still matters, regardless of technological breakthroughs and the implications of globalization.

If to take the Cold War perspective, Crimea was utilized by the Soviets in order to project their power in the Black and Mediterranean seas. This allowed the Soviets to secure the sea corridor to the Middle East where the Kremlin nurtured military and energy partnerships with several states (Delanoe, 2014; Götz, 2015). After 1991 Russia, as the USSR's successor, struggled to regain control over Crimea and thus restore the corridor and re-establish control over the Kerch Strait and the Sea of Azov; the $450 \mathrm{~km}$ of coastline Russia inherited after the Cold War were far from sufficient for the regional projection of power. Not to mention that Russia's Middle Eastern policies were never abandoned. 
As of today, some new arguments should be considered in order to explain the Kremlin's geostrategic thinking. In particular, control over Crimea provides a strong defensive point to Russia "against potential air and sea incursions on its southern flank" (Delanoe, 2013). This particular argument gains extra weight in light of Putin's mistrust towards NATO. The latter - according to Russian President (Putin, 2007) - adherently breaks its promises not to expand eastwards and urges Russia to renew its arms race (Putin, 2015). Indeed, following such antagonistic logics, the situation looks grim from the prospective of the Kremlin. As one may recall, Turkey remains an old and proven NATO member with a modern fleet, Romania hosts the biggest NATO air base in Europe, and several Eastern European states continuously reiterate their NATO aspirations (i.e., Georgia and Ukraine). Thus, Russia urgently needs to feel itself protected from any possible threats and dangers originating in the Black and Mediterranean Sea basins (Götz, 2015). Not to speak of the civil wars and insurgencies smoldering on in the Caucasus and in the Middle East; they do also have significant implications for Russia's security.

In order to address old and new challenges, Russia is prone to modernize its Black Sea Fleet and upgrade its military capabilities. The State Armament Program 2011-2020 should be particularly considered in this regard. As Igor Delanoe writes: "Russia has started a wide modernization program of its military forces - the State Armament Program (SAP) 2011-2020 - and the upgrading of the Russian Black Sea Fleet is believed to be one of the most ambitious parts of it, with the expected commissioning of 15-18 new units" (Delanoe, 2014).

Before the annexation of Crimea, Russia was considerably limited in its rearming ambitions and development of its naval power. One should mention here the bilateral agreements signed between Kyiv and the Kremlin in 1997 and 2010; these agreements imposed restrictions on the amount of troops and vessels Russia could deploy in Crimea. Having annexed the peninsula, the Kremlin unilaterally tipped the scales in its favor. With all restrictions removed, Crimea is doomed to become a major Russian stronghold in the region.

SAP 2011-2020 defines growth of the Russian Black Sea Fleet as one of its key state priorities. Apart from pulling on water 15-18 new units - including ships and submarines - the naval infrastructure of Sevastopol with its eight deep-water bays will be significantly improved (Boltenkov, 2011; Delanoe, 2014; Götz, 2015). Not to mention that the new supportive military bases are to be erected in the occupied Caucasian territories of Abkhasia and South Ossetia. They will host both on-water - whether possible - and land-based units. 
As the purely land-based units in Crimea are concerned, Delanoe writes that: "Russia plans to induct Su-24M and Su-30SM for air strike capacities and Il-38 $\mathrm{N}$ for patrolling and anti-submarine capabilities. The annexation of Crimea has also opened the path to the deployment on the peninsula of new missiles systems such as the Bastion-P coastal battery and S-300 PMU anti-aircraft missiles near Sevastopol, effective since March 2014" (Delanoe, 2014).

All this demonstrates that Russia is deliberately willing to cement its southern flank. Implementation of SAP 2011-2020 along with the recent updates to Naval Doctrine 2011 (e.g., development of the Black Sea ship-building facilities and improvement of the social support for sailors), as well as public statements of Russian officials reveal very unequivocal signals (Bodner, 2015). There are also some intelligence leaks that the Kremlin considers deploying nuclear weapon in Crimea (Keck, 2015). In a word, the annexation of peninsula became a notable move in the Great Russian geopolitical game.

The Ukrainian response to this Russian move is apparently vague. President Petro Poroshenko reiterates that the restoration of Kyiv's authority over Crimea is an issue of major complexity and cannot be fulfilled in the nearest future. In his Annual Address to the Parliament on 4 June 2015, Poroshenko did not refer to the Crimean issue at all (Dzerkalo Tyzhnia June 05, 2015). What is worse, in more than two years after the annexation, Ukraine has not worked out a consistent strategy of returning Crimea; the only thing officials are speculating about resides in granting a special status to Crimea as a Ukrainian territory along with applying all diplomatic efforts possible to restore Ukraine's territorial integrity (Dzerkalo Tyzhnia September 06, 2016).

However, from another perspective, a vague Ukrainian response is an unavoidable digression of a young state that should accept on its way per aspera ad astra; Ukraine is not in a position - de facto - to take a strong individual stance against Russia. So far Kyiv attempts to establish the broadcasting of the state's media on the peninsula, coordinate its diplomatic efforts with foreign partners, and provide any support necessary to the Crimean Tatars (Bianov, 2014). Factually, the only powers consistently defending pro-Ukrainian position and cooperation with the West are the Tatars.

The Russian-Tatar relations have always been tense, or even gravely conflictual. In 1783, after Catherine the Great conquered the peninsula, the Crimea Tatars - indigenous population - were banished and deported. In 1940s, under Stalin's mass deportation policies approximately 200,000 Tatars were forced to move to Central Asia where many of them died. It was only in 1991, after Ukraine 
declared independence, that the Tatars started to return to their homeland. As a result, the Crimean Tatar population counts nowadays approximately 300,000 (Roslycky, 2011).

With the Crimean annexation Tatars are destined to experience new challenges. Their social and political activists are often suppressed by militiamen or prosecuted by the pro-Russian authorities. According to Mustafa Dzhemilev, the Crimean Tatar leader, a total of 18 Tatars were reported missing during the first year of annexation (Shandra, 2015). A majority of them contacted their families later, however some people were found dead. Pro-Russian authorities are also working hard to undermine the power of the Mejlis (one of the highest executive-representative bodies of the Crimean Tatar people) or to create an alternative governing body. For various reasons, selected Tatar individuals agreed to cooperate with the new authorities. However, on a larger scale, Tatars link their well-being with the restoration of Ukrainian sovereignty over Crimea (Shandra, 2015).

To draw intermediary conclusions, Crimea faces hard times at the moment, with no certain prospects for the future. On the one hand, its economy is severely undermined by the broken ties with mainland Ukraine and the targeted Western sanctions. Social activists - mainly of Tatar origin - experience regular violations of human rights and political prosecution. On the other hand, the Russian Black Sea Fleet and other military facilities are well supported and rapidly built up by the Kremlin. Considering the current dynamics, Crimea will become an economically underdeveloped and blockaded territory crammed with weaponry. This is how the contemporary Russian geopolitical interest in the Black Sea Region looks like.

\section{CONCLUDING REMARKS}

With numerous anticipatory signs, on 12 February 2007 President Putin publicly announced some updates to Russia's geopolitical objectives. Delivering a speech at the Munich Conference on Security, he openly criticized the post-Cold War order in the world and positioned Russia as the defiant power. Putin claimed that his state was destined to take an individual stance regarding the conditions imposed by the U.S. unilateral War on Terror, NATO eastward expansion, and the evolving EU neighborhood programs. Moreover, the President condemned Western states in conducting double-faced policies; from Putin's perspective, 
all "colorful revolutions" and the Middle East interventions were nothing but "special operations" by Western states to secure their global domination through promotion of democracy. This type of "deceptive behavior" was totally wrong, according to Putin; what was worse, this placed Russia in a position of inferiority.

To increase Russia’s global geopolitical weight, Putin and the Kremlin analysts decided to "mirror the West" and conduct their own "special operations". This can partially explain Russia's military offensive in Georgia in 2008 and the Crimean annexation from Ukraine in 2014.

Speaking of the latter, it was indeed a special operation considered in advance, much earlier than February 2007. It took years for Russia to establish multicomponent all-penetrating networks in Crimea, wait for a suitable moment, and - finally - undermine Ukrainian governance on the peninsula through selective application of "hard" and "soft" power. It was in 2009 that Volodymyr Horbulin, the Head of the Council for Foreign and Security Policy, stated that Russian strategic goal since $1990^{\text {s }}$ resided in establishing control over - at least - South-Eastern part of Ukraine (Horbulin, Litvinenko, 2009). In turn, in 2011, Roslycky wrote the following about Crimea: "Using the Russian Black Sea Fleet as an element of Russia's hard power, certain activities of Russian intelligence agencies, pro-Russian organizations and other actors were presented in the light of soft power [...]. Activities of the Russian intelligence services (particularly the $642^{\text {nd }}$ Department of Psychological Warfare), the Moscow State University Black Sea Branch and NGOs have targeted every component of Ukraine's soft power security. The Russian Orthodox Church and the Russian Cossacks are also linked to the promotion of religious strife and anti-Western perceptions" (Roslycky, 2011).

Acting in tight coordination with one another under the supervision of Russian intelligence, it took a few weeks in 2014 for Russian networks to transform Crimea into a Russian federal subject.

To justify the change in the status of Crimea, from the perspective of international law, the Kremlin referred to the provisions of Russia's military doctrine and the UN Charter - the latter guarantees the right to every nation for selfidentification - as well as reiterated its intention to protect compatriots abroad. Factually, according to the Kremlin's public statements, the annexation of Crimea was an inevitable taking into account the coup détat in Kyiv, the threats for the Russian speaking minorities in Ukraine, and the results of the referendum in Crimea. These statements did not convince international society, and in particular Western states. The latter even imposed sanctions on Russia in order 
to moderate its geopolitical ambitions and prevent the Kremlin from further interference into Ukrainian affairs.

The history of Russian expansionism - and geopolitical advancements demonstrates that the Kremlin combines strategic long-term planning with spontaneous but well-timed ruthless actions. Having its objectives cautiously concealed or misrepresented, the Kremlin always waits until the right moment to strike. When such a moment comes - as it was with the post-revolutionary weakened Ukraine - all means necessary are utilized to achieve the desirable outcome (Horbulin, 2015). This pattern of expansionist behaviour has a long tradition; one may trace its roots to the times of Tsar Nikolay I or even earlier - to Ivan the Terrible times.

To provide an example, Horbulin states that Stalin's strategic objective in $1930^{\text {s }}$ resided in establishing full control over Lithuania, Latvia, and Estonia. There was never developed, however, a detailed plan how to achieve that objective. Stalin adopted his decisions ad hoc, according to the situation; each step was determined by the weakness of the opponent. This approach proved to be efficient; Baltic States fell under the Soviet rule in 1940 (Horbulin, Litvinenko, 2009).

In the case of Crimea, "Russian President Vladimir Putin said he was ready to put his country's nuclear forces on alert when he annexed Ukraine's Crimean peninsula last year, in case of an intervention by the U.S. and its allies" (Meyer, 2015). As one may deduce, controlling Crimea was a Russian strategic objective; its annexation did not depend on the political loyalty of Ukrainian authorities - it was just a matter of time and opportunity; Crimean annexation required significant courage and improvisation in 2014; in case of any complications, the Kremlin was ready to utilize the most powerful weapon in its arsenal. This said, contemporary Russia is an outward oriented state which utilizes every proper opportunity to expand or indirectly strengthen its influence in the target states ${ }^{7}$.

The geopolitical importance of Crimea to Russia resides in its necessity to add a defensive depth to its southern flank and to nurture the feeling of security in

7 British historian Arnold Toynbee (1889-1975) defined Russia as the permanent Byzantium-type state-empire. Russian leaders were considering their decisions and actions always correct and indisputable. This encouraged them to pursue domestic and foreign policies with totalitarian confidence; state institutions were also appropriately shaped. The nature of the Byzantium state, as described by Toynbee, makes Russia permanently hostile towards the third states, and especially towards the West. These two powers are civilizationally incompatible (for more details see: Civilization on Trial, Toynbee, 1948). 
the face of NATO. The issue of security, apropos, has always been important to the Kremlin. If to refer to George Kennan's "long telegram", written in 1946, the Kremlin's neurotic view of world affairs has always been portraying the outside world as "evil, hostile, and menacing" (Kennan, 1946). On the one hand, this allowed Soviet leaders to strengthen their legitimacy within the state and gain more support from common people. On the other hand, this justified increased military expenditure and fueled Soviet geopolitical expansion. The same pattern - security through expansion - is applicable for $21^{\text {st }}$ century Russia; following this pattern is only the matter of proper opportunities and right circumstances.

If to look even deeper into history, the mentioned above Lypa argued that the constant search for external conflicts was stiffening Russian statehood. "War could be easily started because the majority of the population supported it eagerly: peasants were waging heavy wars with the administration on their lands that they were reluctant, or even looked with hope to gain new territories" (Lypa, 1995). Looking from this perspective, the annexation of Crimea seems to be an ordinary deal for Russia; there were even no objections or protests among the population condemning this act. On the contrary, a majority of Russians were exalted and unanimously approved the deliberations of their leaders. As of now, regardless of deteriorating living standards, Russians still gladly believe the state's propaganda and continue to support their leaders in doing a "just and right thing".

As far as Ukraine's efforts to bring Crimea back are concerned, they can hardly be defined as efficient and sustainable. Moreover, contemporary authorities tend to overlook the issue of annexation in their public speeches; at best they express themselves in general terms. This makes some sense though; in the conditions Ukraine is now - torn between insurgencies and corruption - it cannot afford itself a strong stance against Russia's geopolitical ambitions. Thus, the restoration of Ukrainian sovereignty over Crimea - which inevitably requires the engagement of the West - is not on the agenda now.

Considering the current dynamics, Crimea under Russian rule is transformed into an economically obsolete territory located at the outskirts of world civilization. The only industry which will flourish in Crimea is military; factually, the peninsula will evolve into the abundantly armed anti-NATO fortress. This is how the contemporary Russian geopolitical interest in the Black Sea Region looks like. 
REFERENCES:

Bianov, H. (2014). Polityka "Tykhoyi Dyplomatii": Ukrayina Aktyvizuvala Zusyllia dlia Povernennia Krymu. Retrieved from: http://khersonci.com.ua/politics/8599politika-tikhoji-

diplomatiji-ukrajina-aktivizuvala-zusillya-dlya-povernennya-krimu.html.

Bodner, M. (2015). New Russian Naval Doctrine Enshrines Confrontation with NATO. Retrieved from: http://www.themoscowtimes.com/business/article/new-russiannaval-doctrine-enshrines-confrontation-with-nato/526277.html.

Boltenkov, D. (2011). Reform of the Russian Navy. In: M. Barabanov (ed.), Russia's New Army. Moscow: Center for Analysis of Strategies and Technologies.

Brzezinski, Z. (2014). Confronting Russian Chauvinism. Retrieved from: http://www. the-american-interest.com/articles/2014/06/27/confronting-russian-chauvinism/.

Darczewska, J. (2014). The Anatomy of Russian Information Warfare: The Crimean Operation, A Case

Study. Warsaw: Ośrodek Studiów Wschodnich im. Marka Karpia/Centre for Eastern Studies.

Delanoe, I. (2013). Russia's Plans for Crimea: the Economic Development. In: L. Roslycki, S. Yeremenko (eds.), Harvard Black Sea Security Program. Retrieved from: http://www.harvard-bssp.org/static/files/442/black_sea_2014.pdf.

Delanoe, I. (2014). After the Crimean Crisis: Towards a Greater Russian Maritime Power in the Black Sea. Southeast European and Black Sea Studies, 14(3), 367-382.

Dodds, K. (2007). Geopolitics: a Very Short Introduction. Oxford: Oxford University Press.

Dunham, W. (2014). Kerry Condemns Russia's "Incredible Act of Aggression" in Ukraine. Retrieved

from: http://www.reuters.com/article/2014/03/02/us-ukraine-crisis-usa-kerryidUSBREA210DG20140302.

Flint, C. (2006). Introduction to Geopolitics. London and New York: Routledge.

Forsberg, T., Herd, G. (2015). Russia and NATO: From Windows of Opportunities to Closed Doors. Journal of Contemporary European Studies, 23(1), 41-57.

Gerasimov, V. (2013). Tsennost' Nauki v Predvidenii. Retrieved from: http://vpk-news. $\mathrm{ru} / \mathrm{articles} / 14632$.

Gerber, T.P., Zavisca, J. (2016). Does Russian Propaganda Work? The Washington Quarterly, 39(2), 79-98. DOI: 10.1080/0163660X.2016.1204398.Götz, E. (2015). It's Geopolitics, Stupid: Explaining Russia's Ukraine Policy. Global Affairs, 1(1), 3-10. Horbulin, V., Litvinenko, A. (2009). Bolshoi Sosed Opredelilsia. Chto Ukrainie delat Dal'she? Retrieved from: http://gazeta.zn.ua/POLITICS/bolshoy_sosed_opredelilsya_chto_ukraine_delat_dalshe.html.

Horbulin, V. (2015). "Hibrydna Viina" iak Kluchovyi Instrument Rosiyskoi Geostrategii Revanshu. Retrieved from: http://gazeta.dt.ua/internal/gibridna-viyna-yakklyuchoviy-instrument-rosiyskoyi-geostrategiyi-revanshu-_.html. 
Hughes, J., Sasse, G. (2016). Power Ideas and Conflict: Ideology, Linkage and Leverage in Crimea and Chechnya. East European Politics, 32(3), 314-334.

ICC News Digest No. 7. (2006). Retrieved from: http://www.iccrimea.org/news/newsdigest7.html.

Jackson, B.P. (2006). The “Soft War" for Europe's East. Policy Review, June 01. Retrieved from: http://www.hoover.org/research/soft-war-europes-east.

Keck, Z. (2015). Russia Threatens to Deploy Nuclear Weapons in Crimea. The National Interest,

June 01. Retrieved from: http://nationalinterest.org/blog/the-buzz/russia-threatensdeploy-nuclear-weapons-crimea- 13013.

Kennan, G. (1946). Long Telegram. Retrieved from: http://digitalarchive.wilsoncenter. org/document/116178.

Kushnir, O., Domaradzki, S. (2013). The EU-Ukraine Relations Through the Prism of Human Rights: Tymoshenko Case. Myśl Ekonomiczna i Polityczna, 43(4), 274-298.

Kushnir, O. (2016). Ukrainian Policies in the Black Sea Littoral: History, Current Trends and Perspectives. Journal of Contemporary European Studies, 25(2), 163-179. Retrieved from: http://www.tandfonline.com/doi/abs/10.1080/14782804.2016.12 19845?journalCode $=$ cjea20.

Kuzio, T. (2006). Russian Subversion in the Crimea. Retrieved from: http://www.gmfus. org/commentary/russian-subversion-crimea.

Laruelle, M. (2015). Russia as a "Divided Nation", from Compatriots to Crimea: A Contribution to the Discussion on Nationalism and Foreign Policy. Problems of Post-Communism, 62(2), 88-97.

Lypa, Y. (1942). Chornomorska Doktryna. Warsaw: Ukrainian Black Sea Institute.

Lypa, Y. (1995). Rozpodil Rosiyi. L'viv: Institute of Ethnography - Ukrainian Academy of Sciences.

Meyer, H. (2015). Russia Was Ready for Crimea Nuclear Standoff, Putin Says. Retrieved from: http://www.bloomberg.com/news/articles/2015-03-15/russia-was-readyfor-crimea-nuclear-standoff-putin-says.

Military Doctrine of Russian Federation. (2000). Retrieved from: http://www.ng.ru/ politics/2000-04-22/5_doktrina.html.

Military Doctrine of Russian Federation. (2010). Retrieved from: http://www.scrf.gov. $\mathrm{ru}$ /documents/33.html.

Povernennia Krymu Protiahom Nastupnoho Roku Nemozhlyve - Poroshenko. (2015). Retrieved from:http://dt.ua/POLITICS/povernennya-krimu-protyagom-nayblizhchogo-roku-nemozhlivo-poroshenko-174892_.html.

Putin, V. (2007). Speech and the Following Discussion at the Munich Conference on Security Policy. Retrieved from: http://en.kremlin.ru/events/president/transcripts/24034.

Putin, V. (2014). Transcript: Putin Says Russia Will Protect the Rights of Russians Abroad. Retrieved from: https://www.washingtonpost.com/world/transcript-putinsays-russia-will-protect-the-rights-of-russians-abroad/2014/03/18/432a1e60ae99-11e3-a49e-76adc9210f19_story.html. 
Putin, V. (2015). Discussions Following the Speech on the $19^{\text {th }}$ St. Petersburg International Economic.

Forum. Retrieved from: http://en.kremlin.ru/events/president/news/49733.

Roslycky, L.L. (2011). Russia's Smart Power in Crimea: Sowing the Seeds of Trust. Southeast European and Black Sea Studies, 11(3), 299-316.

Shandra, A. (2015). Crushing Dissent. Timeline of Repressions Against Crimean Tatars in Occupied Crimea. Retrieved from: http://euromaidanpress.com/2015/03/31/ crushing-dissent-timeline-of-repressions-against-crimean-tatars-in-occupiedcrimea/.

Socor, V. (2005). Advancing Euro-Atlantic Security and Democracy in the Black Sea Region. Retrieved from: https://jamestown.org/wp-content/uploads/2016/09/ SocorCongTestimony030805.pdf.

Suslov, M.D. (2014). “Crimea Is Ours!” Russian Popular Geopolitics in the New Media Age. Eurasian Geography and Economics, 55(6), 588-609.

Szostek, J. (2014). Russia and the News Media in Ukraine: A Case of "Soft Power"? East European Politics and Societies, 28(3), 463-486.

The National Security Strategy of the United States of America. (2002). Retrieved from: http://www.state.gov/documents/organization/63562.pdf.

Tsygankov, A. (2015). Vladimir Putin's Last Stand: the Sources of Russia's Ukraine Policy. Post-Soviet Affairs, 31(4), 279-303.

Wawrzonek, M. (2014). Ukraine in the Grey Zone: Between "Russkiy Mir" and Europe. East European Politics and Societies, 28(4), 758-780.

Vystup Poroshenka u Verhoniy Radi: Povnyi Tekst. (2016). Retrieved from: http:/dt.ua/ POLITICS/vistup-poroshenka-u-verhovniy-radi-povniy-tekst-218082_.html.

Zevelev, I. (2014). The Russian World Boundaries. Russia's National Identity Transformation and New Foreign Policy Doctrine. Retrieved from: http://eng.globalaffairs.ru/ number/The-Russian-World-Boundaries-16707. 